\title{
ANALYSIS REACTIVITY OF PUNICA GRANATUM POLYPHENOLS TO THE OSTEOCALCIN, BONE MORPHOGENETIC PROTEIN-2, AND COLLAGEN TYPE-1
}

\author{
EDRIZAL BURHAN ${ }^{1,2}$, BERGMAN THAHAR ${ }^{3}$, TRIMURNI ABIDIN ${ }^{4}$, DEDDI PRIMA PUTRA $^{5}$, BASRI A GANI ${ }^{6}$ \\ ${ }^{1}$ Department of Orthodontic, Dentistry Faculty, Baiturahmah University, Padang, Indonesia. ${ }^{2}$ Department of Doctoral Program, Dentistry \\ Faculty, North Sumatera University, Medan, Indonesia. ${ }^{3}$ Department of Orthodontic, Dentistry Faculty, Padjajaran University, Bandung \\ Indonesia. ${ }^{4}$ Department of Conservative, Dentistry Faculty, North Sumatera University, Medan, Indonesia. ${ }^{5}$ Department of Pharmacy, \\ Andalas University, Padang, Indonesia. ${ }^{6}$ Department of Oral Biology, Dentistry Faculty, Syiah Kuala University, Banda Aceh, Indonesia. \\ Email: basriunoe@unsyiah.ac.id
}

Received: 11 September 2018, Revised and Accepted: 24 October 2018

ABSTRACT

Objective: Punica granatum (PG) contains anthocyanins which are useful as antioxidants, anti-inflammatory, and prevent cancer, while also increasing bone cell proliferation and osteoblasts differentiation in bone remodeling.

Methods: The reactivity of osteocalcin protein markers with PG polyphenol fractionation hydrogels observed using enzyme-linked immunosorbent assay, the degree of reactivity was determined by optical density at $550 \mathrm{~nm}$.

Results: PG butanol fraction has better reactivity compared to the total extract, ethyl, and hexane fraction. Based on the reactivity distribution, bone morphogenetic protein (BMP)-2 and collagen Type-1 had a dominant distribution compared to osteocalcin, but the theses proteins had a strong relation $(r=0.8)$ with probability $(P<0.05)$.

Conclusion: PG butanol fraction had better reactivity to osteocalcin, BMP-2, and collagen Type-1 compared with total extract, hexane, and ethyl fraction. The four PG polyphenol fractionations have dominant reactivity to BMP-2.

Keywords: Punica granatum, Reactivity, Osteocalcin, Bone matrix protein-2, Collagen Type-1.

(C) 2018 The Authors. Published by Innovare Academic Sciences Pvt Ltd. This is an open access article under the CC BY license (http://creativecommons. org/licenses/by/4. 0/) DOI: http://dx.doi.org/10.22159/ajpcr.2018.v11i12.29683

\section{INTRODUCTION}

Pomegranate (Punica granatum [PG]) peel contains proanthocyanidin which is a family of flavonoids [1]. This active component acts as an antioxidant, anticancer, and also anti-inflammatory by inhibiting proinflammatory cytokines [2]. Moreover, these active components can also inhibit a number of enzymes that play a role in cell differentiation such as cyclooxygenase, lipooxygenase, cytochrome P450, phospholipase A2, ornithine decarboxylase, carbonic anhydrase, 17 beta-hydroxysteroid dehydrogenase, and serine protease [3].

PG peel extract contains various active components that differ depending on the extractor which used. The largest phenolic levels were found in butanol fraction compared to other extractors. The ethanol extract of PG peel produces a number of polyphenols which can trigger the expression of angiogenesis cells in the process of new bone formation [4]. A number of studies have reported that PG polyphenol fractionation has a significant effect on osteoblast cell viability as well as curcumin polyphenol fractionation as an immunostimulator for osteoblast expression in bone remodeling case [5]. The pomegranate peel of the Ganesh variety that extracted with ethanol and methanol was evaluated for the phenol content which contained at those extract. Methanol extract has better immunotolerant potency against pathogens than ethanol extract, while a mixture of ethanol and methanol extract has a very good antioxidant potency with phenol content in it which can act as an antibacterial either antioxidant [6].

Siddiqui et al. reported that PG can increase bone cell proliferation and osteoblast differentiation that is characterized by the expression of the runt-related transcription factor 2 (Runx2) gene. This assumption can be used as a reference for osteoporosis medication [7]. Meanwhile, PG ethanol extract can also be used as an anti-osteoporosis drug due to its ability to induce glucocorticoid hormones in osteoporosis mice model [8]. Furthermore, Bahtiar et al. reported that the use of PG polyphenol fractionation in concentrations of 50,100, and $200 \mathrm{mg} / \mathrm{kg}$ can significantly prevent bone loss, this is related to an increase in bone calcium, particularly by increasing osteoblast [9], likewise in ovariectomy case, PG can be a stimulus to prevent bone loss [10]. The ability of PG in bone remodeling had been used to be a reference for this study, so the aim of this study was to test the ability of PG that interacts with proteins involved in bone remodeling such as osteocalcin, bone morphogenetic protein (BMP)-2, and collagen Type-1.

\section{MATERIALS AND METHODS}

Material

This study has passed ethical clearance from the Dentistry Faculty, North Sumatra University, Medan-Indonesia. This study used PG polyphenol fractionation as the assay material to measure the degree of reactivity from osteocalcin, BMP-2, and collagen Type-1 (Abcam, Cambridge, USA) proteins. The Enzyme-linked Immunosorbent Assay (ELISA) assay will be used to the reactivity analysis PG polyphenol with the bone marker proteins as the indicator of bone remodeling.

\section{Extraction and fractionation of PG}

The first stage is the extraction and fractionation of PG as a test material based on methods that had been done by Arma et al. [11]. $900 \mathrm{~g}$ of fresh PG peel that has been cleaned and peeled off, wind dried for $2 \times 24 \mathrm{~h}$, cut into small pieces and mashed. Subsequently macerated with $96 \%$ ethanol (1:10) $9 \mathrm{~L}$ for $24 \mathrm{~h}$ and stirred in the first $6 \mathrm{~h}$. On the $2^{\text {nd }}$ day, the macerate was filtered (macerate I), the pulp continued maceration with $96 \%$ ethanol (1:5) $4.5 \mathrm{~L}$ for $24 \mathrm{~h}$. On the $3^{\text {rd }}$ day, the macerate was filtered and merged with the macerate I. Furthermore, the solvent was evaporated so that a thick extract of $1164.4 \mathrm{~g}$ was obtained. Fractionation 
was then carried out into polyphenols, where the extract was diluted with aquadest and then fractionated with $4 \times 500 \mathrm{~mL}$-hexane which produced 3.25-g hexane fraction. Fractionation was then also carried out too with ethyl acetate $5 \times 500 \mathrm{~mL}$ which obtained $13.9 \mathrm{~g}$ ethyl acetate fraction. Then, the least fractionation with $5 \times 500 \mathrm{~mL}$ butanol was obtained $44 \mathrm{~g}$ butanol fraction.

Determination of total phenol levels was carried out using the FolinCiocalteu method, by measuring the indicator of gallic acid. $4 \mathrm{mg}$ gallic acid was dissolved in $10 \mathrm{~mL}$ ethanol (400 ppm) with various concentrations ( $30 \mathrm{ppm}, 40 \mathrm{ppm}, 50 \mathrm{ppm}, 60 \mathrm{ppm}$, and $70 \mathrm{ppm}$ ). The absorbance of the solution was measured with the Folin-Ciocalteu method and carried out as follows: The sample was put into a plate, then $50 \mathrm{ml}$ of Folin reagent $7.5 \%$ was added. $50 \mu \mathrm{l}$ of a sample was put into it and incubated for $8 \mathrm{~min}$, then added $1 \% \mathrm{NaOH}$ followed by incubation for $1 \mathrm{~h}$. The absorbance of gallic acid expression was measured by spectrophotometry at $730 \mathrm{~nm}$. Determination of total phenolic levels equivalent of gallic acid was carried out using the FolinCiocalteu method, with gallic acid as a comparison, assuming that all phenolics contained in the extract or fraction specified total phenolic content were considered as gallic acid or gallic acid equivalents.

\section{Reactivity assay by ELISA}

The ELISA technique was adopted from Gani et al. [12] to find out the lowest concentration of the PG fraction which still shows reactivity to bone marker proteins (osteocalcin, BMP-2, and collagen Type-1). Then, the concentration of the test material was measured based on optical density (OD) at $655 \mathrm{~nm}$. The OD that obtained was used to get the concentration based on the conversion with the standard formula $(\mathrm{OD} \times 7.65)-0.3=\mu \mathrm{g} / \mathrm{ml})$.

The ELISA test was carried out by entering $200 \mu$ l of each PG polyphenol fractionation sample to 96-well plate (triplo) which had been converted to its concentration value and shaken at $200 \times g$ for $5 \mathrm{~min}$, then incubated at room temperature for $1 \mathrm{~h}$ and washed with Tween- 20 for 3 times. Furthermore, in each well was added $200 \mu \mathrm{l}$ of $5 \%$ non-fat milk and incubated on a shaker for $1 \mathrm{~h}$ at room temperature and washed with Tween-20 for 3 times. After that, each marker protein for osteocalcin, BMP-2, and collagen Type- 1 was dissolved in 5\% non-fat milk with a ratio of 1:2000, diluted to get a concentration of $100 \mu \mathrm{g} / \mathrm{ml}$, then put into the well.

In the first well was added $200 \mu \mathrm{l}$ of each bone marker protein and the next well was $100 \mu \mathrm{l}$ each, then dilution was carried out leveled 8 times, sequentially $(1000,500,250,125,62.5,31.25,18.62$, and 7.81) after that incubated on a shaker for $1 \mathrm{~h}$ at room temperature and washed with Tween-20 for 3 times. In each well was added $100 \mu \mathrm{l}$ of anti-protein marker antibody (HRP - rabbit anti-osteocalcin, BMP-2, and collagen Type- 1 IgG $(\mathrm{H}+\mathrm{L})$ with a ratio of 1:5000 and incubated on a shaker for $1 \mathrm{~h}$ at room temperature, then washed with Tween-20 solution for 3 times. Moreover, in each well was added $50 \mu$ of ELISA substrate solution and placed in a dark room for $20 \mathrm{~min}$. The reaction that occurred between PG polyphenol fractionation and bone marker protein was stopped by adding $50 \mathrm{~mL}$ of $\mathrm{HCl} 1 \mathrm{~N}$. The result was read with an ELISA reader based on OD at $550 \mathrm{~nm}$.

\section{Statistical analyses}

PG polyphenol fractionation percentage profile which identified by bone marker protein was analyzed using parametric and nonparametric tests with $p<0.05$ as a determinant of statistical significance and correlation $(\mathrm{r}=1)$ as a determinant of the relationship between the analyzed variables.

\section{RESULTS AND DISCUSSION}

The gallic acid of PG polyphenol fractionations has value above equivalent to $150 \mathrm{mg} / \mathrm{ml}$. The butanol fraction has gallic acid equivalent $(157.62 \mathrm{mg} / \mathrm{ml})$ more dominant than hexane fraction $(113.81 \mathrm{mg} / \mathrm{ml})$, ethyl fraction has $155.90 \mathrm{mg} / \mathrm{ml}$, and extract total (ethanol extract) of PG has $169.61 \mathrm{mg} / \mathrm{ml}$ of gallic acid.
Bone formation metabolism consists of the balance of matrix deposition, mineral formation, and reabsorption [13]. The herbs used had been reported to have an effect on the process of new bone formation, specifically inhibiting bone reabsorption. Garlic and parsley have been reported could inhibit bone reabsorption and osteoclast activity which causes an increase in mineral density in ovariectomy cases [14]. PG has $50 \%$ active components, where phenolics and flavonoids are the dominant ones and very important as phytochemicals [15]. In addition, there are $40 \%$ water, sugar, pectin, and organic acids such as ascorbic acid, either $10 \%$ fibers, vitamins (E, C, and $\mathrm{K}$ ), polysaccharides, and minerals [16].

Based on measurements of total phenolic from extraction and fractionation, $\mathrm{PG}$ phenolic levels were found to be quite high, especially in the butanol fractionation. These results proved that ethanol extract from PG peel produces optimal polyphenols in triggering angiogenesisosteoblast cells by inducing osteocalcin, BMP-2, and collagen type- 1 . This way gives the possibility of PG can play a role in bone remodeling. PG has a number of active components that contribute to bone repair by inducing bone marker proteins [17]. The results of this study showed that PG polyphenol fractionation has good reactivity to all three bone marker proteins (Figs. 1-3).

ELISA test used a based concentration to measure the lowest concentration titers that still show good reactivity. This study used eight different concentrations $(\mu \mathrm{g} / \mathrm{ml})(1000,500,250,125,62.5$, $31.25,18.62$, and 7.81$)$. The results of OD $(550 \mathrm{~nm})$ was obtained scale reactivity 1.11> (strong), 1.1-1.10 (medium), and <1.09 (low). From these results, each PG polyphenol fractionation was averaged to obtain a percentage value of bone marker reactivity as shown in Figs. 1-3.

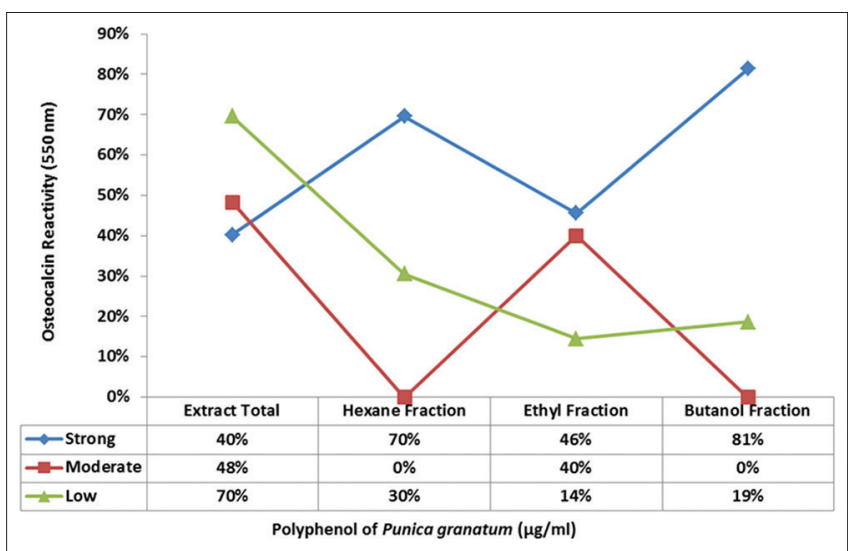

Fig. 1: Reactivity of osteocalcin protein on the Punica granatum polyphenol

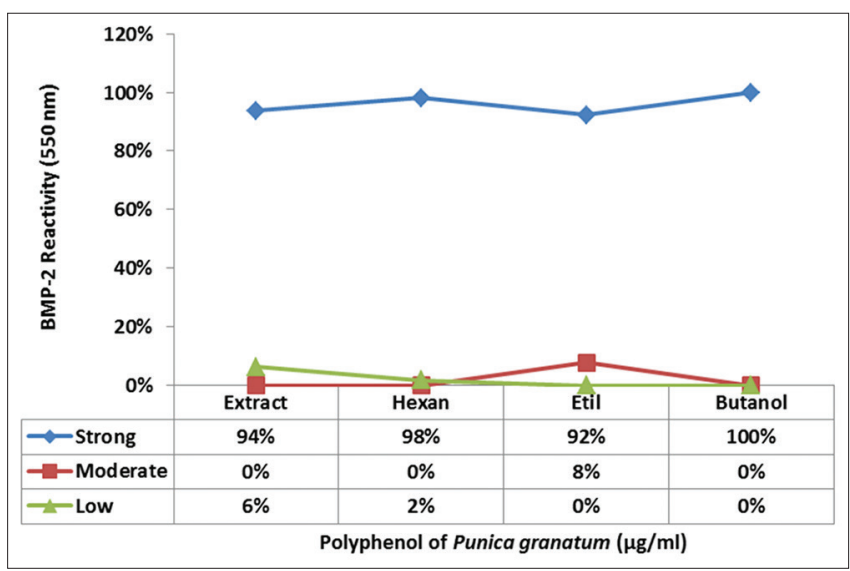

Fig. 2: Reactivity of bone morphogenetic protein-2 protein on the Punica granatum polyphenol 
PG butanol fraction has a very strong reactivity to osteocalcin, followed by hexane and ethyl fractionation (Fig. 1). PG polyphenols are reported to play a role in the osteogenic activity. Giving PG with concentrations of $10,100,1000$, and $10,000 \mu \mathrm{g} / \mathrm{ml}$ can increase the number of cartilage nodules in cartilage formation, so it can be recommended that PG can increase bone formation [18]. Osteocalcin protein plays a role in bone calcium formation, with a molecular weight $5.8 \mathrm{KDa}$ and amounts about $10-12 \%$ of the total non-collagen protein, this protein is closely related to the bone mineralization phase [19]. Some other bone proteins such as thrombopoietin, glycoprotein acids, and fibronectin are proteins that contain arginine-lysine aspartate acid which has a large affinity for calcium formation, these proteins have the ability to be bound by integrin receptors [20]. Growth factors and cytokines such as transforming growth factor beta (TGF- $\beta$ ), insulin growth factor, interleukin, and BMP are present in small amounts in the bone matrix, where the protein binds bone mineral and the matrix will then release during bone resorption by osteoclasts [21].

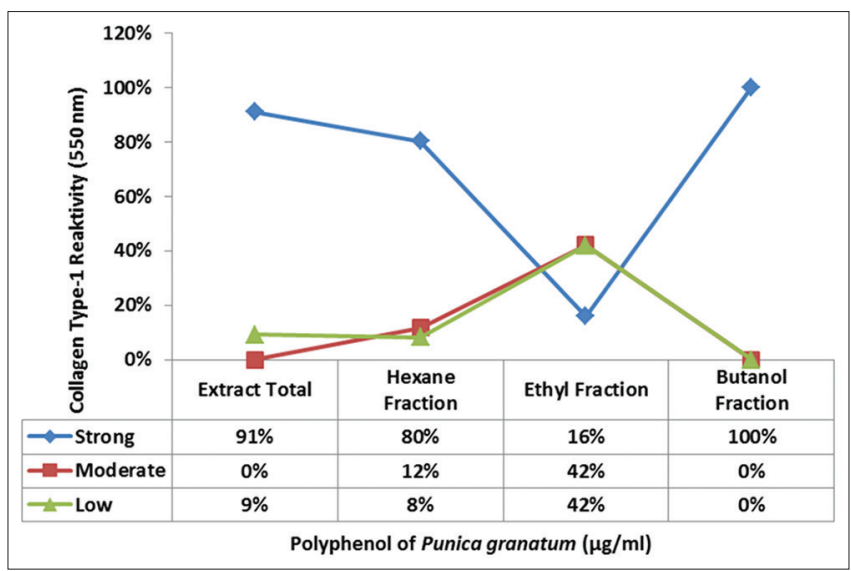

Fig. 3: Reactivity of collagen Type-1 protein on the Punica granatum polyphenol

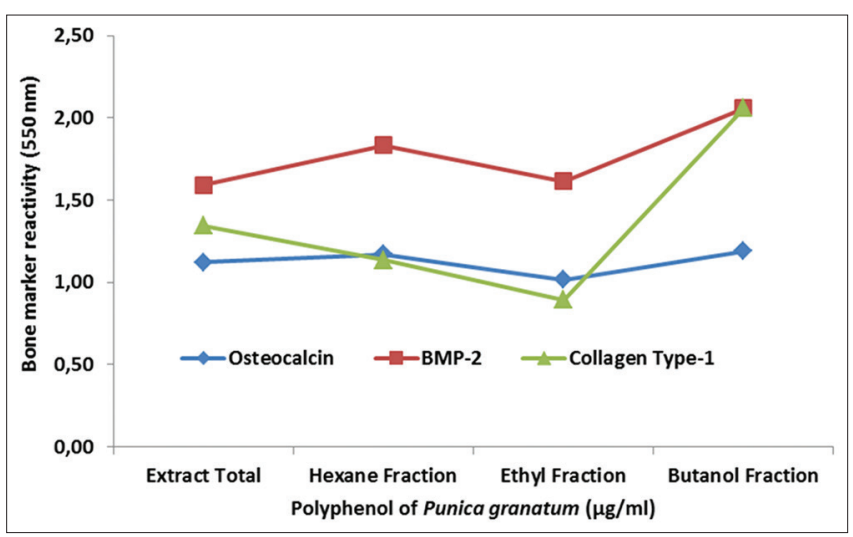

Fig. 4: Distribution and frequency reactivity of bone marker protein (osteocalcin, bone morphogenetic protein-2, and collagen Type-1) to the Punica granatum polyphenol
Osteocalcin serum was reported acts as a marker of bone turnover associated with osteoporosis [22]. In general, osteocalcin serum can increase new bone formation [23]. Lansky et al. reported that the amount of substance from PG ellagic acid can increase the signal for new bone formation [24]. Wnt/ $\beta$-catenin from PG is an active component that acts to increase the signal for osteogenesis increased. Specifically, ellagic acid can increase osteopontin and osteocalcin [25]. PG seed oil extract was reported to play a role as a bone biomarker, specifically to detect osteocalcin [26]. This activity linked with the increase of the Runx2 gene $(\mathrm{p}<0.001)$ which triggers the expression of proteins that involved in new bone formation. This indicated that PG can prevent bone loss by increasing the activity of inflammatory responses and stress oxidative [4].

Fig. 2 shows BMP-2 bone markers having excellent reactivity to PG butanol fractionation, even though all PG polyphenol fractionations had strong reactivity against BMP-2. The proliferation and differentiation of osteoblasts mediated by growth factors such as BMPs, TGF- $\beta$, and corebinding factor alpha 1 , which are reported as osteogenic receptor targets associated with the Runx2 [27]. This indicated that PG polyphenols fractionations may be able to induce the expression of BMP-2 when bone remodeling occurs by maintaining osteoblast activity and controlling osteoclast [28]. Giving PG with a concentration of $100 \mu \mathrm{g} / \mathrm{ml}$ can increase bone nodule formation which illustrated the occurrence of osteoblast differentiation within 21 days [29], by increasing calcium and osteoblasts as an indicator of BMP-2 expression [30]. Giving PG with this concentration can increase calcium deposits up to $68.85 \%$ $(p<0.001)$ compared to controls. This ability is a form of an extracellular matrix that can regulate osteogenic tissue expression [31]. The results also showed that PG polyphenol fractionation has the ability to bind the osteocalcin, BMP-2, and collagen Type-1 starting at concentrations of $1000,500,250,125,62.5,31.25,18.62$, and $7.81 \mu \mathrm{g} / \mathrm{ml}$.

The collagen Type- 1 has a very good sensitivity to PG butanol fractionation (Fig. 3) and the PG better than effect reactivity to BMP-2 compared the osteocalcin and collagen Type-1 (Fig. 4). In line with other studies using butanol fractionation of L. ferrugineus extract also had better results compared to other fractionation in inhibiting phenylephrine at aortic cardiovascular disorders [32]. PG can improve the function of osteoblasts which play an important role in bone remodeling by inducing the expression of bone collagen protein (collagen Type-1) which indicates that PG has anti-osteoporosis ability and can be used as an alternative herb for new bone repair [7]. The results were in line with this study (Table 1) which showed osteocalcin, BMP-2, and collagen Type- 1 had significant differences when tested with PG polyphenols fractionations $(\mathrm{p}<0.05)$. Research using mice model shown that collagen Type-1 can improve implant bone remodeling [33]. In addition, BMP-2 was also involved in maintaining osteoblasts balance to maintain bone integrity [34]. The result from PG polyphenols fractionations which were tested with osteocalcin, BMP-2, and collagen Type- 1 markers indicating that PG can be used as an herbs alternative in bone remodeling after endodontic movement.

Meanwhile using ANOVA one-way test as shown in Table 1, BMP-2 had a normal distribution data with significant differences results between all of PG polyphenol fractionations $(\mathrm{p}<0.05)$ with a strong correlation $(\mathrm{r}=0.8)$. Furthermore, non-parametric statistics with Mann-Whitney test showed osteocalcin had significant differences between all PG

Table 1: Statistical analysis of bone marker protein in various Punica granatum polyphenol

\begin{tabular}{|c|c|c|c|c|c|c|c|c|}
\hline \multirow{2}{*}{$\begin{array}{l}\text { Protein bone } \\
\text { marker }\end{array}$} & \multicolumn{4}{|c|}{ Optical density (550 nm) } & \multicolumn{4}{|c|}{ Statistical descriptive } \\
\hline & $\begin{array}{l}\text { Extract } \\
\text { total }\end{array}$ & $\begin{array}{l}\text { Hexane } \\
\text { fraction }\end{array}$ & $\begin{array}{l}\text { Ethyl } \\
\text { fraction }\end{array}$ & $\begin{array}{l}\text { Butanol } \\
\text { fraction }\end{array}$ & Mean $\pm S D$ & $\mathbf{p}$ & $\mathbf{r}$ & Analysis \\
\hline Osteocalcin & 1.12 & 1.17 & 1.01 & 1.189 & $1.073 \pm 0.01$ & $\mathrm{p}<0.05$ & 0.6 & Non-parametric \\
\hline BMP-2 & 1.59 & 1.83 & 1.61 & 2.06 & $1.148 \pm 0.01$ & $\mathrm{p}<0.05$ & 0.8 & One-way ANOVA \\
\hline Collagen Type-1 & 1.34 & 1.14 & 0.89 & 2.06 & $1.150 \pm 0.01$ & $\mathrm{p}<0.05$ & 0.8 & Non-parametric \\
\hline
\end{tabular}

P. granatum: Punica granatum, BMP: Bone morphogenetic protein 
polyphenol fractionations $(\mathrm{p}<0.05)$ with Spearman's correlation $(r=0.6)$. Other than that, collagen Type- 1 also had significant differences between all PG polyphenol fractionations based on the Friedman test $(p<0.05)$ with a strong relationship based on Spearman's correlation $(\mathrm{r}=0.809)$.

\section{CONCLUSION}

The PG butanol fractionation had better reactivity to osteocalcin, BMP-2, and collagen Type- 1 compared to total extracts, hexane, and ethyl fractions. In general, the four PG polyphenol fractionations have the dominant reactivity to BMP-2.

\section{ACKNOWLEDGMENTS}

Gratefulness to the Biota and Pharmacy Laboratory, Andalas University, West Sumatra; Integrated Laboratory, Gadjah Mada University, Yogyakarta; Biology Laboratory, University of North Sumatra, Medan; and the Laboratory of Microbiology and Pathology, Faculty of Veterinary Medicine, Syiah Kuala University, Banda Aceh.

\section{AUTHORS' CONTRIBUTIONS}

EZ was carried out the conception and research design including the methods assessment also drafted the manuscript with BAG and TA. DPP was analyzed biological effect of PG. Specifically, BAG has been arranged the manuscript, statistical analysis, and corresponding author. All of the authors were read and approved the final manuscript.

\section{CONFLICTS OF INTEREST}

The authors declare that there are no conflicts of interest.

\section{REFERENCES}

1. Rahimi HR, Arastoo M, Ostad SN. A comprehensive review of Punica granatum (Pomegranate) properties in toxicological, pharmacological, cellular and molecular biology researches. Iran J Pharm Res 2012;11:385-400.

2. Rasheed Z, Akhtar N, Anbazhagan AN, Ramamurthy S, Shukla M, Haqqi TM, et al. Polyphenol-rich pomegranate fruit extract (POMx) suppresses PMACI-induced expression of pro-inflammatory cytokines by inhibiting the activation of MAP kinases and NF-kappaB in human KU812 cells. J Inflamm (Lond) 2009;6:1

3. Kusmardi K, Hermanto D, Estuningytas A, Tedjo A, Priosoeryanto BP. The potency of Indonesia's pomegranate peel ethanol extract (Punica granatum linn.) as anti-inflammatory agent in mice colon induced by dextran sodium sulfate: Focus on cyclooxygenase- 2 and inos expressions. Asian J Pharm Clin Res 2017;10:370-5.

4. Spilmont M, Léotoing L, Davicco MJ, Lebecque P, Mercier S, Miot-Noirault E, et al. Pomegranate and its derivatives can improve bone health through decreased inflammation and oxidative stress in an animal model of postmenopausal osteoporosis. Eur J Nutr 2014:53:1155-64.

5. Bharti AC, Takada Y, Aggarwal BB. Curcumin (diferuloylmethane) inhibits receptor activator of NF-kappa B ligand-induced NF-kappa B activation in osteoclast precursors and suppresses osteoclastogenesis. J Immunol 2004;172:5940-7.

6. Malviya S, Arvind, Jha A, Hettiarachchy N. Antioxidant and antibacterial potential of pomegranate peel extracts. J Food Sci Technol 2014;51:4132-7.

7. Siddiqui S, Arshad M. Osteogenic potential of Punica granatum through matrix mineralization, cell cycle progression and runx2 gene expression in primary rat osteoblasts. Daru 2014;22:72.

8. Banu J, Varela E, Fernandes G. Alternative therapies for the prevention and treatment of osteoporosis. Nutr Rev 2012;70:22-40.

9. Bahtiar A, Arifin S, Razalifha A, Qomariah N, Wuyung PE, Arsianti A. Polar fraction of Punica granatum L. Peel extract increased osteoblast number on ovariectomized rat bone. Int J Herbal Med 2014;2:65-70.

10. Spilmont M, Léotoing L, Davicco MJ, Lebecque P, Miot-Noirault E, Pilet $\mathrm{P}$, et al. Pomegranate peel extract prevents bone loss in a preclinical model of osteoporosis and stimulates osteoblastic differentiation in vitro. Nutrients 2015;7:9265-84

11. Arma U, Satari MH, Ilyas S, Handayani D, Primasari A,Kasuma N, et al.Immunogenicity analysis of triterpene glycoside from holothuria atra to detecting fas and BCL-2 protein on the SP-C1 cell of tongue carcinoma. Asian J Pharm Clin Res 2018;11:248-52.

12. Gani B.A, Bachtiar BM, Winiati EB, Wibawan IWT. The ability of IgY to recognize surface proteins of Streptococcus mutans. Dent J Majalah Kedokteran Gigi 2009;42:189-93.

13. Priyanka MJ, Jaiganesh D. Periodontally accelerated osteogenic orthodontics. Int J Pharm Pharm Sci 2013;5:49-51.

14. Putnam SE, Scutt AM, Bicknell K, Priestley CM, Williamson EM. Natural products as alternative treatments for metabolic bone disorders and for maintenance of bone health. Phytother Res 2007;21:99-112.

15. Rajan S, Mahalakshmi S, Deepa VM, Sathya K, Shajitha S, Thirunalasundari T. Antioxidant potentials of Punica granatum fruit rind extracts. Int J Pharm Pharm Sci 2011;3:82-8.

16. Miguel G, Fontes C, Antunes D, Neves A, Martins D. Anthocyanin concentration of Assaria pomegranate fruits during different cold storage conditions. J Biomed Biotechnol 2004;2004:338-42.

17. Sreekumar S, Sithul H, Muraleedharan P, Azeez JM, Sreeharshan S. Pomegranate fruit as a rich source of biologically active compounds. Biomed Res Int 2014;2014:1-12.

18. Monsefi M, Parvin F, Talaei-Khozani T. Effects of pomegranate extracts on cartilage, bone and mesenchymal cells of mouse fetuses. Br J Nutr 2012;107:683-90.

19. Vinoth JK, Patel KJ, Lih WS, Seow YS, Cao T, Meikle MC, et al. Appliance-induced osteopenia of dentoalveolar bone in the rat: Effect of reduced bone strains on serum bone markers and the multifunctional hormone leptin. Eur J Oral Sci 2013;121:517-24.

20. Robey PG, Fedarko NS, Hefferan TE, Bianco P, Vetter UK, Grzesik W, et al. Structure and molecular regulation of bone matrix proteins. J Bone Miner Res 1993;8 Suppl 2:S483-7.

21. Fang B, Wan YZ, Tang TT, Gao C, Dai KR. Proliferation and osteoblastic differentiation of human bone marrow stromal cells on hydroxyapatite/bacterial cellulose nanocomposite scaffolds. Tissue Eng Part A 2009;15:1091-8.

22. $\mathrm{Ng} \mathrm{KW}$. Potential role of odanacatib in the treatment of osteoporosis. Clin Interv Aging 2012; 7:235-47

23. Civitelli R, Armamento-Villareal R, Napoli N. Bone turnover markers: Understanding their value in clinical trials and clinical practice. Osteoporos Int 2009;20:843-51.

24. Lansky EP, Newman RA. Punica granatum (pomegranate) and its potential for prevention and treatment of inflammation and cancer. J Ethnopharmacol 2007;109:177-206.

25. Al-Obaidi MM, Al-Bayaty FH, Al Batran R, Hassandarvish P, Rouhollahi E. Protective effect of ellagic acid on healing alveolar bone after tooth extraction in rat--a histological and immunohistochemical study. Arch Oral Biol 2014;59:987-99.

26. Shaban NZ, Talaat IM, Elrashidy FH, Hegazy AY, Sultan AS. Therapeutic role of Punica granatum (Pomegranate) seed oil extract on bone turnover and resorption induced in ovariectomized rats. J Nutr Health Aging 2017;21:1299-306.

27. Yamaguchi A, Komori T, Suda T. Regulation of osteoblast differentiation mediated by bone morphogenetic proteins, hedgehogs, and cbfa1. Endocr Rev 2000;21:393-411.

28. Chen G, Deng C, Li YP. TGF- $\beta$ and BMP signaling in osteoblast differentiation and bone formation. Int J Biol Sci 2012;8:272-88.

29. Bonnelye E, Chabadel A, Saltel F, Jurdic P. Dual effect of strontium ranelate: Stimulation of osteoblast differentiation and inhibition of osteoclast formation and resorption in vitro. Bone 2008;42:129-38.

30. Morris C, Thorpe J, Ambrosio L, Santin M. The soybean isoflavone genistein induces differentiation of MG63 human osteosarcoma osteoblasts. J Nutr 2006;136:1166-70.

31. Muthusami S, Senthilkumar K, Vignesh C, Ilangovan R, Stanley J, Selvamurugan $\mathrm{N}$, et al. Effects of cissus quadrangularis on the proliferation, differentiation and matrix mineralization of human osteoblast like saOS-2 cells. J Cell Biochem 2011;112:1035-45.

32. Ameer OZ, Salman IM, Siddiqui MJ, Yam MF, Sriramaneni RN, Sadikun A, et al. Cardiovascular activity of the n-butanol fraction of the methanol extract of loranthus ferrugineus roxb. Braz J Med Biol Res 2010;43:186-94

33. Rammelt S, Schulze E, Witt M, Petsch E, Biewener A, Pompe W, et al. Collagen Type I increases bone remodelling around hydroxyapatite implants in the rat tibia. Cells Tissues Organs 2004;178:146-57.

34. Shahi M, Peymani A, Sahmani M. Regulation of bone metabolism. Rep Biochem Mol Biol 2017;5:73-82. 